\section{The Rise and Fall of a Policy Rule: Monetarism at the St. Louis Fed, 1968-1986}

\author{
R. W. Hafer and David C. Wheelock
}

"Once the quantity theory regained academic respectability, it was obliged to resume responsibility for the short-run forecasting of aggregate movements of prices and quantities ... This it has begun to do, most importantly through the research work of the Federal Reserve Bank of St. Louis, and with appreciable success; but it has been lured into playing in a new ballpark, and playing according to a different set of rules than it initially established for itself ... [I]ts own success is likely to be transitory, precisely because it has relied on the same mechanisms of intellectual conquest as the [Keynesian] revolution itself . . . and has also espoused a methodology that has put it in conflict with long-run trends in the development of the subject."-Harry Johnson (1971, pp. 12-13)

M acroeconomists today generally agree that monetary policy cannot permanently increase the rate of economic growth above its potential or decrease the rate of unemployment below its market clearing, or "natural," level (e.g., De Long, 2000; Woodford, forthcoming). In the long run, monetary policy affects only the rate of inflation, and many economists argue that monetary policy can best promote maximum sustainable economic growth by ensuring price level

R. W. Hafer is a professor of economics and finance, and Director, Office of Economic Education and Business Research, Southern Illinois University Edwardsville. David C. Wheelock is an assistant vice president and economist at the Federal Reserve Bank of St. Louis. Heidi L. Beyer provided research assistance. The authors thank Anatol Balbach, Rachel Balbach, Michael Bordo, Keith Carlson, Brad DeLong, Bill Dewald, Jerry Dwyer, Milton Friedman, Gail Heyne Hafer, Joe Haslag, Bob Hetzel, Ali Kutan, Thomas Mayer, and Anna Schwartz for comments on an earlier draft. The authors also thank Gloria Valentine of the Hoover Institution for her assistance with the Friedman papers. stability (e.g., Barro, 1996). Monetary policymaking, however, both in the United States and elsewhere, is often concerned with the short-run. Policymakers meet frequently: the Federal Reserve's Open Market Committee (FOMC) meets eight times a year, for example, and a vote is taken at each meeting on whether to maintain or change the current stance of policy. While price stability is widely acknowledged as the appropriate long-run objective of monetary policy, many economists argue that policymakers should respond to fluctuations in real output or employment as part of their strategy to achieve price stability and, ultimately, to support maximum sustainable economic growth. ${ }^{1}$

To help guide them in their deliberations, policymakers and their economic advisors rely on both complex economic and econometric models and on simple rules-of-thumb based on empirical regularities observed in macroeconomic data. Indeed, simple rules, such as the so-called Taylor rule (Taylor, 1993), which describes the response of the federal funds rate to past deviations of inflation and output from target values, often appear to explain well how policymakers set policy in the short-run. Economists generally conclude that rules-based policies are preferable to those relying solely on the discretion of policymakers. The transparency of rules reduces uncertainty about the responsiveness of policy to economic change and can enhance the accountability of policymakers.

Monetarists have long advocated the use of rules to guide monetary policy, with Friedman's (1960) proposal for a constant money stock growth rate being the most famous example. At the time it was made, Friedman's proposal was sharply at odds with the prevailing mainstream view that monetary policy was best conducted by manipulating interest rates to strike a balance between inflation and unemployment. At the time, economists widely believed in the power of activist monetary and, especially, fiscal policy to limit fluctuations in economic activity and to ensure sufficient demand to provide full employment economic growth over extended periods. Friedman's "monetarist" policy rule thus attracted considerable attention. Moreover, a growing body of empirical work by Friedman and others showing the potential for money supply shocks to have large short-run impacts on output and employ-

\footnotetext{
For a recent argument along these lines, see Mishkin (2000) and the references cited therein.
} 
ment led to the development of an alternative framework for conducting stabilization policy based on targeting growth of the money stock.

The Federal Reserve Bank of St. Louis played an important and highly visible role in the development and advocacy of stabilization policy based on the targeting of monetary aggregates. This article examines the development of the monetaristbased stabilization policy framework advocated by the St. Louis Bank between the late 1960s and the 1980 s, with an eye toward identifying lessons from that experience for the conduct of stabilization policy in general. ${ }^{2}$

This article also illustrates how the Federal Reserve System's decentralized structure fosters a climate of internal debate. Beginning in the 1960s, the monetary policy actions advocated by the St. Louis Bank in its research publications, in public forums, and in the participation of the Bank's presidents in policy meetings often were sharply at odds with the policies adopted by the Federal Reserve System. The Fed's decentralized structure permitted the development of alternative policy views and the exploration of new ideas within the System (Wheelock, 2000). Policy debates often took place within System publications. We describe the public debate as we trace the evolution of the St. Louis Fed's monetarist policy, and the criticism of that policy by other Fed officials, in the Federal Reserve Bank of St. Louis Review, other System publications, and in the public speeches of Darryl Francis, President of the Federal Reserve Bank of St. Louis from 1966 to 1976.

To provide a backdrop to our discussion, the next section summarizes the dominant policy positions taken by economists during the 1960s and early 1970s about the causes of inflation and the role of monetary policy. We point out key issues where monetarists disagreed with the conventional wisdom. In the subsequent two sections we review the research and policy positions taken by St. Louis Fed economists and officials from the 1960 s through the early 1980s. We limit our discussion mainly to the period 1968-86. In 1968, the Federal Reserve Bank of St. Louis published an econometric analysis of the relative impacts of monetary and fiscal policy on economic activity. That article, by Andersen and Jordan (1968), became one of the most cited papers in economics in the past 40 years. In 1970, the Bank published the first version of its monetarist model for gauging the impact of monetary policy actions on economic activity (Andersen and Carlson, 1970).
The year 1986 marked the appearance of the final version of that model (Carlson, 1986). We show how research conducted at the Federal Reserve Bank of St. Louis extended earlier monetarist analysis that had focused on the role of money in explaining economic activity in the long run. Their success in finding apparently robust, stable relationships in both long- and short-run data led monetarists to apply long-run propositions to short-run policy questions, effectively competing with alternative views of the time. When the short-run correlation between money and economic activity went astray in the early 1980s, however, the efficacy of the monetarist rule and appeals for targeting monetary aggregates to achieve economic stabilization quickly lost credibility.

\section{THE SETTING: FINE-TUNING THE ECONOMY}

The 1960s were the glory days of activist, short-run stabilization policy. Policymakers had confidence in their ability to achieve full employment using fiscal and monetary policy to "fine tune" or manage aggregate demand. For a time, their confidence seemed justified: Before the present expansion, the 1960s witnessed the longest uninterrupted expansion in U.S. history, with the economy operating at full employment (defined then as a civilian unemployment rate of 4 percent or less) from 1966 to 1969.

Beginning in 1965, however, rising inflation and an increasing balance of payments deficit reflected the cost of expansionary macroeconomic policies. Policymakers felt increasing pressure to control inflation but were hesitant to take actions that might reduce employment and real output growth. Because policymaking was viewed as striking a balance between inflation and unemployment, disagreements about policy, according to one Fed governor, boiled down to one's preferences between the two outcomes. ${ }^{3}$ Because unemployment frequently was viewed as a more

\footnotetext{
2 The defining characteristics, technical aspects, and legacy of mone tarism in general have been explored elsewhere, e.g., DeLong (2000), Melzter (1998), Rasche (1993), and Woodford (forthcoming).

3 Governor Sherman Maisel argued at an FOMC meeting on October 20,1970 , "that at least some of the Committee's differences on policy reflected difference in basic value judgments regarding the relative importance of various conflicting goals-for example, regarding the appropriate trade-off between employment and price stability" (FOMC Minutes, October 20, 1970, p. 41)
} 
serious concern than inflation, for many years the Fed opted for maintaining an inflationary bias in monetary policy to avoid higher rates of unemployment. Fed officials, like other government officials, argued that the inflation-unemployment tradeoff could be improved only through the cooperation of business and labor in the setting of prices and wages or, if necessary, by the use of anti-trust and other polices to make price setting more competitive. Alternatively, inflation could be controlled through explicit regulation of wages and prices

Juxtaposed against this mainstream view was an alternative associated with the work of Milton Friedman, Anna Schwartz, Karl Brunner, Allan Meltzer, and other so-called monetarists. Monetarism was rooted in the Quantity Theory of Money. The core of the Quantity Theory is that, in the long run, inflation reflects excessive growth of the money stock relative to real output growth, the latter determined fundamentally by non-monetary forces such as population growth and productivity. An important component of this position is the stability of the public's demand for money. Monetarists amassed empirical evidence showing the demand for money to be more stable than money supply or, equivalently, that velocity is stable. ${ }^{4}$ Stability of velocity supported monetarists' view that short-run fluctuations in economic activity often are caused by fluctuations in money supply growth-fluctuations brought about by central bank policy actions. 5 Monetarists concluded that central bank attempts to manipulate interest rates had led to destabilizing fluctuations in money supply growth and, therefore, in economic activity. Hence, monetarists argued that monetary policymakers should minimize the variation of the growth rate of the money stock both in the shortrun and over time. Lags in assessing economic conditions and in the effects of policy actions on economic activity, they argued, made attempts at "fine tuning" a balance between inflation and unemployment futile. Instead, monetarists argued for a policy that maintained growth of the money stock at a low, fixed rate, irrespective of the business cycle.

The Federal Reserve Bank of St. Louis was the center of monetarism within the Federal Reserve System from the 1960s into the 1980s. ${ }^{6}$ Darryl Francis, who became president of the St. Louis Bank in 1966, was an especially strong advocate of monetarist policy prescriptions. At FOMC meetings, he argued frequently for a policy of minimizing variability in money stock growth around a moderate trend. In public forums, Francis made the case that growth of the money stock was the most accurate reflection of monetary policy and that excessive monetary growth was the fundamental cause of inflation. Francis was supported in his policy views by St. Louis Fed economists, whose research findings were largely in accord with those of other monetarists but sharply at odds with the conventional wisdom of the times, including the views about monetary policy held in most quarters of the Federal Reserve System.

\section{Mainstream Views About Monetary Policy in the 1960s}

A review of monetarism and all of its differences with mainstream Keynesian macroeconomics of the 1960s is beyond the scope of this article. Sharp theoretical differences about the cause or causes of inflation and economic fluctuations, as well as methodological differences about the empirical analysis of the effects of policy actions on economic activity, however, are fundamental to understanding why St. Louis Fed research and policy positions were controversial. These differences include whether a tradeoff exists between inflation and unemployment, either in the short or the long run, and whether such a tradeoff is exploitable by policymakers. A related question is whether monetary policy can, or should, be used to fight inflation when the economy is at less-than-full employment. Monetarists and non-monetarists divided also over the measures that best reflect the impact of monetary policy actions-monetary aggregates or interest rates and credit aggregates. Finally, monetarists and non-monetarists debated the tools and methods for identifying the impact of monetary policy on the economy.

\footnotetext{
4 Velocity was stable not as an arithmetic constant, but in the sense that its behavior was related predictably to changes in the opportunity cost of holding money and to changes in income or wealth of individuals.

5 Perhaps the most famous statement and evidence of this proposition is Friedman and Schwartz (1963).

6 Consider Friedman's (1992) appraisal: "The interesting thing to me has always been that the most important contributions to understanding of monetary theory and monetary institutions have not come from Washington during the decades in which I've been active. The Federal Reserve Bank of St. Louis in the 1950s, '60s and '70s was by far and away the pre-eminent producer of significant monetary research within the System."
} 


\section{Inflation and the Phillips Curve}

The Phillips curve-the inverse relationship between unemployment and wage growth in British historical data observed by Phillips (1958) - was a key empirical regularity at the heart of macroeconomic policy discussions in the 1960s. The Phillips curve was viewed as a constraint on stabilization policy; policymakers with both unemployment and inflation goals had to choose a feasible combination of the two because policies that, say, reduced inflation would invariably slow economic activity and increase unemployment. Perry (1966, p. 3) noted that

a fairly general consensus exists among economists ... [that s] uccessively higher levels of activity are associated, roughly at least, with correspondingly larger rates of price increase. In this situation, the more traditional problem of adjusting aggregate demand so as to reach full employment without overshooting into the area of inflation must be replaced with the dual problems of deciding what combination of unemployment and inflation to aim at and then adjusting aggregate demand to reach this point.

Fed governor Sherman Maisel (1973, p. 14) observed succinctly: "There is a trade-off between idle men and a more stable value for the dollar. A conscious decision must be made as to how much unemployment and loss of output is acceptable in order to get smaller price rises."

Although many influential economists believed that the hyperbolic shape and negative slope of the Phillips curve were fixed, it was clear that the position of the Phillips curve could move over time. The U.S. experience of 1955-58 was widely discussed: In 1955-57, the unemployment rate hardly changed when the inflation rate increased sharply; in 1958, when inflation abated, the increase in the unemployment rate seemed disproportionately high. Concern arose that the U.S. economy had an "inflation bias," meaning that inflation, perhaps accelerating inflation, was necessary to achieve and maintain full employment (Wheelock, 1998).

The experience of 1955-58 gave prominence to the notions of "cost-push" inflation and "wageprice spirals." The term cost-push inflation was used to define an ongoing increase in the general level of prices caused by firms passing along increases in production costs, in contrast to "demand-pull" inflation caused by increases in aggregate demand. Cost-push forces were thought to explain how inflation could occur at less than full employment. The "essence of the problem," according to Samuelson and Solow (1960, p. 181), stems from the absence of perfect competition in factor and product markets and was, Bronfenbrenner and Holzman (1963) noted, associated with the power of "economic pressure groups," such as labor unions and monopolistic firms. If a powerful union extracts a real wage increase, the quantity of labor demanded falls. If affected firms have pricing power, they pass along a portion of the increase in wages to consumers in the form of higher prices. If perfect competition exists in other industries and labor markets, prices and wages fall to offset the increases in the first industry. If wages are downwardly rigid throughout the economy, however, the aggregate price level might rise alongside an increase in unemployment.

Throughout the 1960s, the Economic Report of the President blamed inflation on "excessive" wage and price increases. The clear implication was that monetary and fiscal policies were not responsible for inflation when the economy was at less than full employment. The Economic Report for 1965 explained that "in a world where large firms and large unions play an essential role, the cost-price record will depend heavily upon the responsibility with which they exercise the market power that society entrusts to them" (1966, p. 179). Hence, President Johnson urged, "in the strongest terms I know - that unions and business firms exercise the most rigorous restraint in their wage and price determinations" (Economic Report of the President for 1967, p. 20). Throughout the 1960 s the Economic Report published detailed wage and price "guideposts" defining the extent to which wage and price increases were "justifiable."

Monetarists dismissed the notion of cost-push inflation, arguing that inflation is "always and everywhere a monetary phenomenon." Nonmonetarists generally accepted that "cost-push may involve increases in money supply, money income, and money expenditures, particularly if decreases in output and employment are to be avoided" (Bronfenbrenner and Holzman, 1963, p. 614). Nonetheless, many economists found monetary explanations of inflation wanting, claiming that inflation can arise through wage and price setting independent of shocks to aggregate 
demand. The short-run linkages from money to inflation were considered to be tenuous at best. ${ }^{7}$

Economists generally did acknowledge the potential for restrictive monetary policy to eliminate cost-induced inflation. The apparent downward rigidity of prices and wages, however, convinced many that using monetary policy to arrest even a moderate inflation would entail a substantial and unacceptable increase in unemployment. The Economic Report of the President for 1961 (p. 47) claimed that "an attempt to restrict aggregate demand so severely as to eliminate all risk of an increase in the general price level might well involve keeping the economy far below full employment." 8 High unemployment was simply an unacceptable cost of reducing inflation. In his introduction to the 1967 Report (p. 20), President Johnson argued, "Dealing with inflation by creating a recession or persistent slack is succumbing to the disease-not curing it. The experience of 1957 and 1958-when the unemployment rate reached $7 \frac{1}{2}$ percent and consumer prices still rose 5 percent-is a clear reminder of the large costs of such a policy and of its limited effectiveness in halting a spiral in motion. This is a course which I reject."

To fight inflation, some mainstream economists advocated incomes policies; others favored policies aimed at enhancing the competitiveness of product and labor markets and policies aimed at raising productivity. Monetary policy, many argued, should focus on maintaining full employment by keeping interest rates low.

Many Federal Reserve officials expressed similar qualms about using monetary policy to control inflation. For example, Charles Partee, a Fed staff economist who later became a Fed governor, argued in 1970 that "The question is whether monetary policy could or should do anything to combat a persistent residual rate of inflation ... The answer, I think, is negative." He added that "Product markets generally are substantially underutilized and labor appears to be readily available ... It seems to me that we should regard continuing increases [in the price level] as a structural problem not amenable to macro-economic measures" (FOMC Minutes, April 1970, pp. 385-86, 379, 396 [quoted in Mayer (1999), p. 99]). Federal Reserve Board Chairman Arthur Burns also argued that "Monetary policy could do very little to arrest an inflation that rested so heavily on wage-cost pressures ... A much higher rate of unemployment produced by monetary policy would not moderate such pressures appreciably" (FOMC Minutes, June 8, 1971, p. 51).

\section{The Long-Run Phillips Curve}

Wage and price rigidity and the possibility of cost-induced inflation suggested to many observers that using monetary policy to contain inflation would invariably cause higher unemployment. Monetarists did not deny this, but argued that the tightening of monetary policy would have merely a temporary adverse impact on unemployment. Andersen (1973), for example, argued that "our economic system is such that disturbing forces, including even changes in money growth, are rather rapidly absorbed and ... output will naturally revert to its long-run growth path following a disturbance" (p. 7).

Some economists, however, argued that using monetary or fiscal policy to achieve price stability might cause unemployment to increase permanently. Keynesians frequently interpreted the Great Depression as indicating that private demand might be insufficient to generate full employment output in the face of downwardly rigid wages and prices, thereby leaving the economy mired permanently at less than full employment. Thus, many economists believed that monetary and fiscal policy should ensure that aggregate demand is sufficient to generate full employment, even if that requires some inflation. Samuelson (1960, p. 265), for example, argued that "With important cost-push forces assumed to be operating, there are many models in which it can be shown that some sacrifice in the requirement for price stability is needed if short- and long-term growth are to be maximized, if average long-run unemployment is to be minimized, if optimal allocation of resources as between different occupations is to be facilitated."

The Fed often was accused of paying "excessive" attention to price stability. In summarizing a symposium on recent monetary policy, Harris (1960, p. 245) wrote, "In general the disagree-

\footnotetext{
7 Ackley (in Perlman, 1965, p. 47), for example, wrote that "I do not consider the change in money supply of much short-run importance." Weintraub (1960, p. 280) contended that "contrary to the widespread belief that there is a direct tie of money supplies to price levels, the modus operandi of monetary policy is different: its immediate effect is upon consumption and investment demands, thereby upon employment levels, and only indirectly affecting the general level of money wages" (emphasis in the original).

8 The Council of Economic Advisors at this time consisted of Walter Heller, Kermit Gordon, and James Tobin.
} 
ments of [participating] economists with Federal Reserve policy have stemmed primarily from a fear that the interest in the stability of the currency has been at the expense of growth and employment." 9 Not only was the tradeoff between inflation and unemployment widely viewed as persistent, but some economists argued that policies to achieve price stability in the short-run might make the tradeoff less favorable over time. Samuelson and Solow (1960), for example, believed that policies directed at limiting inflation in the short-run might increase structural unemployment. The long-run tradeoff between inflation and unemployment would worsen because an increase in structural unemployment would raise the size of the increase in inflation that would be needed to achieve a given reduction in the unemployment rate. Perry (1966, p. 119) even suggested that policies aimed at maintaining low unemployment and minimizing short-run cyclical variation in output could moderate wage and price increases. ${ }^{10}$

\section{The Impact of Monetary Policy}

Economists' conviction that policymakers could manipulate aggregate demand to stabilize the growth of real output reached its zenith in the 1960 s and early 1970s. The apparent failure of low interest rates to revive the economy during the Great Depression, however, was taken as evidence that monetary policy is less potent than fiscal policy. The 1950s witnessed the development of new theories about the impact of monetary policy, with the dominant view being that policy is effective through its influence on both the cost and availability of credit. ${ }^{11}$ Still, even in the 1960s, the mainstream view was that monetary policy, though capable of having some impact, was less powerful than fiscal policy. ${ }^{12}$

Monetarists, by contrast, argued that changes in the quantity of money exert a powerful influence on economic activity. Friedman's work during the 1950s helped establish the foundation for later studies of the link between monetary policy and the economy (e.g., Friedman, 1956). His examination of monetary policy and the business cycle is reflected in his testimony to the Joint Economic Committee in March 1958. ${ }^{13}$ At that time, most Fed officials believed that short-term interest rates and the quantity of bank credit were the appropriate instruments of monetary policy. Minutes of FOMC meetings reveal that policymakers generally rejected the notion that movements in the money supply affect economic activity, much less that the Fed can control the money stock. Although one or two FOMC members warned persistently that fluctuations in money growth could cause undue fluctuations in the real economy, these concerns largely were ignored. ${ }^{14}$

Outside the Fed, by contrast, monetarist views about the impact of fluctuations in money stock growth were receiving considerable attention. Friedman and Meiselman's (1963) "The Relative Stability of Monetary Velocity and the Investment Multiplier in the United States, 1897-1958," for example, stirred much debate. Associated with the Commission on Money and Credit's inquiry into the structure of the financial system, this paper was controversial because it rejected a core ingredient in the Keynesian theoretical structure-the validity of the expenditure multiplier. Friedman

\footnotetext{
9 Angell (1960, p. 248) argued similarly, stating that "As to aggregate growth, a good many students feel-as do I - not only that monetary policy has not done much to promote it, but that the intermittent restrictions imposed to fight instability and inflation have probably retarded it substantially." Hansen (1960, pp. 255-56) proposed that "Monetary policy should seek to achieve a low long-run rate of interest" to raise permanently the ratio of investment to out put and thus real growth, while fiscal policy could "offset ... the inflationary pressures caused by the increase in investment incident to rapid technological advance and low interest rates."

${ }^{10}$ Policymakers often agreed with such assessments. The Economic Report of the President for 1965 concluded "Rising prices that originate from such a [cost-push] process can affect expectations, jeopardize the stability and balance of an expansion, and create inequities and distortions just as readily as demand inflation. But measures to restrain these price increases by reducing over-all demand will enlarge unemployment and impair the productivity record so important to cost-price stability over the longer run" ( $p$. 179). The Council of Economic Advisors at this time consisted of Gardner Ackley, Otto Eckstein, and Arthur Okun.

11 The "Availability Doctrine" posits that small changes in interest rates can have large economic effects by affecting banks' willingness to supply loans. The theory was developed by New York Fed economist Robert Roosa (1956) and was the dominant view of the transmission mechanism within the Fed at the time. See Johnson (1962) for a survey of current thinking on monetary theory and policy effectiveness as of the early 1960 s.

12 The consensus view is perhaps well represented by Ando et al. (1963, p. 2), who concluded "the effect of monetary policy on the flow of expenditures is far from overwhelming, though it exists and is of a magnitude worth exploiting in the interests of economic stability ... Our findings on fiscal policy are primarily that variations in disposable income, either through transfer payments or personal income tax changes, can operate as a powerful short-run stabilizer."

13 This testimony was based on on-going research with Anna J. Schwartz at the National Bureau of Economic Research. This research was subsequently published in three volumes: see Friedman and Schwartz (1963, 1970, 1982).

${ }^{14}$ In the late 1950s and early 1960s, Malcolm Bryan, President of the Federal Reserve Bank of Atlanta, argued that the Fed should target the growth rate of total reserves, and minimize fluctuations in the money stock. See Meigs (1976) and Hafer (1999).
} 
and Meiselman's empirical analysis also found money demand to be relatively more stable than money supply, suggesting that observed movements in the money stock and economic activity are dominated by Fed policy actions rather than by volatility in the public's demand for money.

The debate that ensued was so important that the American Economic Review devoted an entire issue to critical appraisals of the FriedmanMeiselman (1963) study by Ando and Modigliani (1965) and DePrano and Mayer (1965) and a response by Friedman and Meiselman (1965). ${ }^{15}$ Two issues were key to the attacks and rejoinder. One was Friedman and Meiselman's finding that velocity is relatively more stable than the Keynesian expenditure multiplier. In other words, output appeared to be related more to movements in money than to other measures of autonomous expenditure.

The other issue, one that is more important for what would later be the attack on the St. Louis approach, was the procedure Friedman and Meiselman used to produce that finding. The debate displayed a fundamental difference in views about how to estimate economic relationships for policy purposes. Friedman and Meiselman, whose work was grounded in the tradition of the Quantity Theory of Money, based their conclusions on simple reduced-form relations observed in the data. Ando and Modigliani (1965) argued that such simple regressions, not much more than correlations, were inferior to the output of the large-scale, structural models then coming into vogue to evaluate policy. In other words, though different approaches may produce different results, only the most sophisticated is useful for policy analysis. ${ }^{16}$

Many Federal Reserve officials embraced the use of large-scale econometric models then being developed. Board staff participated with economists from the Massachusetts Institute of Technology in constructing the FRB-MIT model, which was used for policy analysis and evaluation at the Board. Such models were widely judged superior to single-equation or small-model systems for studying the effects of policy actions on economic activity. An official of the Federal Reserve Bank of New York argued that large-scale models produced "quantitative estimates of the timing and magnitude of the effects of central bank actions on the money supply and other financial magnitudes and the subsequent effects, in turn, of these variables on each of the various major components of aggregate demand" (Davis,
1968, p. 73). Thus, large structural models appeared to give policymakers the information they needed to make short-term, fine-tuning policy adjustments to stabilize economic activity.

\section{Monetary Policy Target}

Alongside large-scale macroeconometric models, the 1960s witnessed the development of increasingly complex analyses of the effects of monetary policy actions, interacting with financial regulatory policies, on financial flows and interest rates. With the exception of monetarists, many macroeconomists believed that monetary policy was not represented accurately by the behavior of any single variable, such as the rate of interest, the quantity of bank credit, or the stock of money. This view was reflected in the Economic Report of the President for 1968:

In the formulation of monetary policy, careful attention should be paid to interest rates and credit availability as influenced by and associated with the flows of deposits and credit to different types of financial institutions and spending units. Among the financial flows generally considered to be relevant are: the total of funds raised by nonfinancial sectors of the economy, the credit supplied by commercial banks, the net amount of new mortgage credit, the net changes in the public's holdings of liquid assets, changes in time deposits at banks and other thrift institutions, and changes in the money supply. Some consideration should be given to all of these financial flows as well as to related interest rates in formulating any comprehensive policy program or analysis of financial conditions. (p. 89)

The Report also dismissed monetarist appeals for focusing on money stock growth. In response to calls for setting monetary policy according to a

\footnotetext{
15 This is the so-called AM-FM or "radio" debate. Hester (1964) was also critical of the Friedman-Meiselman approach.

${ }^{16}$ Brunner (1986) provides an excellent and wide-ranging overview of this debate. He defends the Friedman-Meiselman (1963) approach, arguing that "the use of a single equation with a single independent variable should now be clear. It was the appropriate choice for an assessment of the core class [of hypotheses]. It did not represent a single equation model or a [direct] disposition to favor simple, as against sophistical models" (p. 41, emphasis in original). Rather, Brunner suggests (p. 40) that "the strong assertions conveyed by the basic core of the income-expenditure approach, which frequently spilled over into categorical policy statements, were thus shown to have little substantive foundation."
} 
fixed-growth rule for the money stock, the Report argued (p. 92) that "given the complex role of interest rates in affecting various demand categories and the likely variations in so many other factors, any such simple policy guide could prove to be quite unreliable." Similar reasoning was reflected in the analysis of Federal Reserve Board economists. In a paper published in the Federal Reserve Bulletin, Gramley and Chase (1965, pp. 1403-04) wrote that "the money stock [is] an untrustworthy indicator of the effects of policy actions on financial asset prices and yields ... Financial market behavior is too complex for simple monetary rules to work." 17

Monetarists, of course, disagreed that the complexity of financial markets made targeting a monetary aggregate infeasible. In an article in the Journal of Political Economy, Federal Reserve Bank of St. Louis economist Leonall Andersen (1968) presented evidence that the Fed could use open market operations to smooth fluctuations in total and free (i.e., excess less borrowed) reserves and, by implication, in the monetary base. ${ }^{18}$ Albert Burger (1971), another St. Louis Fed economist, presented a detailed analysis of how the monetary base can be manipulated so as to control the money stock.

The Fed's ability to control monetary aggregates and the efficacy of monetary control for economic stabilization remained hotly debated issues. They also were central research themes at the Federal Reserve Bank of St. Louis throughout the 1960s and 1970s.

\section{ST. LOUIS-THE LONG-RUN VIEW}

Under the leadership of its director of research, Homer Jones, the Federal Reserve Bank of St. Louis emerged as the center of monetarist economics within the Federal Reserve System in the early 1960s. ${ }^{19}$ The Bank's Review, which then appeared monthly, tracked the behavior of the economy and the money stock in nearly every issue. Review articles often described the recent behavior of the money stock and related it to monetary growth during previous expansions. For example, the June 1962 article, "Monetary Developments," compared graphically the recent behavior of bank reserves and the money stock (M1) with their patterns during the 1953-57 and 1957-60 cycles. This type of chart, used by Friedman in his 1958 Senate testimony and in Friedman and Schwartz (1963), provided a visual analysis of expansionary and contractionary movements of the money stock.

A companion article in the June 1962 Review provided one of the first monetarist explanations from the St. Louis Fed of how monetary policy actions are transmitted to changes in nominal income and prices. The article, "Changes in the Velocity of Money: 1951-1962," addressed one of the more difficult questions monetarists faced in attempting to use the Quantity Theory to explain how monetary policy affects the economy in the short-run. If velocity is highly variable, then the connection between changes in the money supply and nominal income is uncertain at best. The article provided a "tentative and exploratory analysis" of the behavior of velocity. The analysis showed that a "rapid change in money [is] to be matched temporarily by an opposite change in velocity" (p. 13). Over time, however, "as the public recognized the change in its [money] balances ... there was an increase in spending, and velocity moved upward" (p. 13). Using this pattern to explain the effects of past policies, the article noted that "Within a few months after money began expanding at a rapid rate in 1954, 1958, and 1961, spending and the velocity of money began rising" (p. 13).

The article is an early example of the research coming out of St. Louis in support of the monetarist position that changes in nominal income largely reflect prior movements in the money supply. Even though velocity might vary, its variability appeared to be less than that of money supply. Hence, monetarists argued, observed cycles in

\footnotetext{
${ }^{17}$ It was a long-standing view among Board officials that monetary policy should not focus on any one variable. For example, as early as 1932, Governor Eugene Meyer stated: "Our credit machinery is entirely too delicate and responsive to too many influences to make it desirable to have any one indicator, whether it be the price level or the level of member bank reserves, be the sole guide in determining credit policy" (quoted by A. James Meigs in a letter to Milton Friedman: Friedman Papers, Hoover Library, Stanford University, Box 30, Folder 17)

18 See also Meigs (1966), who reviews the debate about whether finan cial innovation had made control of the money stock infeasible or inefficacious.

19 Jones was hired by the St. Louis Fed in 1958. At that time, the Bank's research staff consisted of one Ph.D. economist, two graduate students, an agricultural economist, a geographer and several junior staff members. During 1958, Jones corresponded regularly with Friedman concerning potential hires for the department (Friedman Papers, Hoover Library, Stanford University, Box 28, Folder 36). In recognition of Jones' accomplishments, in 1976 a special issue of the Journal of Monetary Economics was devoted to papers in his honor.
} 
nominal income growth are caused mainly by changes in the money supply - over which the Fed has some control-rather than by changes in velocity.

As inflation worsened over the 1960s, Review articles reflected an increasingly aggressive application of monetarist arguments by St. Louis Fed economists, as critical reviews of policy replaced tentative and exploratory studies. For example, a July 1966 article, titled "Total Demand and Inflation," stated that "Excessively stimulative Government policies lead to marked increases in the price level. Rapid monetary expansion is regarded by many as a means of stimulating total demand" (p. 1). In the same issue, Keran (1966) studied the relationship between nominal and real output in eight countries. He concluded that inflation results when total demand-nominal income-rises faster than the economy's potential rate of real output growth, suggesting that "If the recent acceleration in total demand is continued at a time of high-level resource utilization, prices will probably begin to rise even faster" (p. 12). In addition, Keran hinted at the possibility of using monetary policy for short-run stabilization, noting that "To the extent that policy tools control the growth in total demand they are useful in achieving cyclical stability in the economy because yearto-year movements in real output can be influenced by changes in total demand" (p. 12, emphasis added). These and other Review articles, many of which were written anonymously, reflect clearly the monetarist-oriented research and policy analysis carried out by St. Louis Fed economists in the early-to-mid 1960s.

The St. Louis Bank's visibility increased significantly, however, with the publication of articles by Andersen and Jordan (1968) and by Andersen and Carlson (1970). These articles provided two of monetarism's most challenging attacks on policy orthodoxy and mainstream Keynesian macroeconomics. The former presented an econometric evaluation of the relative impacts of monetary and fiscal policy on economic activity. The latter offered a small monetarist econometric model that the authors proposed as an alternative tool to simulate alternative policy scenarios. Both papers concluded that changes in the growth of nominal income and inflation are linked closely to changes in the growth rates of monetary aggregates.

Although such relationships had been demonstrated over relatively long time-horizons, these two articles suggested that they hold over even the short time horizons of concern to policymakers. The articles were instrumental in developing the monetarist policy rule as an alternative to the conventional interest rate and fiscal-policy oriented ideas of the time.

\section{The Andersen-Jordan Equation}

Andersen-Jordan (1968) (hereafter, AJ) is an intellectual and analytical descendant of Friedman-Meiselman (1963). ${ }^{20}$ Andersen and Jordan, like Friedman and Meiselman, were interested in isolating statistically the impact of money on nominal income. AJ went further, however. They provided a straightforward empirical test of a related and critical policy issue - the relative impacts of monetary and fiscal impulses on nominal income. Rather than building a complex econometric model like those in vogue at the time, AJ took a relatively simple approach to assessing alternative policies. They estimated a single empirical relation-a "reduced-form" model-between income and different measures of monetary and fiscal policy actions. Their equation can be written as:

$$
\Delta Y_{t}=\sum_{i=0}^{3} \beta_{i} \Delta M_{t-i}+\sum_{j=0}^{3} \delta_{j} \Delta E_{t-j}+\varepsilon_{t}
$$

where $Y$ represents nominal gross national product, $M$ is the money stock (M1 or the monetary base), and $E$ is a measure of fiscal policy actions. The variables were measured as changes in their levels. In their estimation, AJ accounted for lags in the effect of policy actions on economic activity using a new econometric technique that constrained the estimated parameters to lie along a predetermined polynomial. This was thought to provide more precise estimation of the effects of changes in the policy variables. ${ }^{21}$

\footnotetext{
20 Jordan (1986) refers to it as a "sequel" to Friedman-Meiselman (1963), though it clearly is linked to earlier work by Karl Brunner. This is evident in the statement by $\mathrm{AJ}$ that their purpose is not to "test rival economic theories [i.e., Keynesian vs. Monetarist] of the mechanism by which monetary and fiscal actions influence economic activity" (AJ, 1986, p. 29). A decade earlier Brunner was examining the logical structure of empirically testing between Keynesian models, in which money played a very minor role, and monetary models, in which "money matters." For example, Brunner and Balbach (1959) present a structure of models in which they test empirically the relative roles of money and fiscal policy actions.

${ }^{21}$ See Batten and Thornton (1986) and the articles cited therein for a discussion of this and other technical issues regarding the estimation of equation (1).
} 
Using quarterly data covering the period 1952 to mid-1968, AJ estimated equation (1) to test three hypotheses. By comparing the sizes of the estimated impacts of fiscal and monetary policy on GNP, AJ rejected the hypothesis that output responds more to fiscal policy actions than to changes in the money stock. Comparison of the statistical significance of the coefficient estimates for monetary and fiscal policy actions led AJ to reject the hypothesis that fiscal actions have a more "reliable" impact on GNP than monetary actions. Finally, comparison of coefficient estimates on lagged monetary and fiscal policy actions, led $\mathrm{AJ}$ to reject the hypothesis that fiscal actions affect GNP faster than do monetary policy actions. They succinctly summed up their evidence: "The response of economic activity to monetary actions compared with that of fiscal actions is (I) larger, (II) more predictable, and (III) faster" (p. 22).

\section{Early Criticism of Andersen-Jordan (1968)}

Andersen-Jordan (1968) was subject to immediate and critical analysis by economists inside and outside of the Federal Reserve System.

Technical criticisms have been dealt with at length elsewhere. ${ }^{22}$ Of interest here is the fact that much of the early debate over the usefulness and the conclusions of the article took place among Fed economists within the pages of System publications. For example, the first published criticism of the AJ approach and findings was by DeLeeuw and Kalchbrenner (1969), both of whom were or had been with the Board of Governors. ${ }^{23}$ Their comment was published in the Federal Reserve Bank of St. Louis Review, along with a response by AJ. DeLeeuw and Kalchbrenner (hereafter, DK) raised several technical issues, but focused on AJ's use of the monetary base as the appropriate measure of monetary policy. DK argued that the Fed controls neither the borrowed reserves of member banks nor the currency stock. Hence, they argued, the base is not statistically independent of the model's dependent variable - changes in GNP. DK reestimated the AJ equation, using the base less borrowed reserves and currency as the monetary policy variable, and found that, although monetary policy appeared "to exert a powerful influence" on GNP, money was not as dominant as AJ's results had suggested. DK noted also that their results were more consistent with the output from large-scale econometric models, suggesting that their results were more plausible than those of AJ.

Another early criticism of AJ appeared in the Monthly Review of the Federal Reserve Bank of New York (Davis, 1969). That study defended the view that monetary policy affects income through interest rates, not the money stock or monetary base, with its author noting that the St. Louis equation "portrays a world in several respects [that is] sharply at variance with the expectations of most of us" (p. 121). Like DK, Davis reestimated the $\mathrm{AJ}$ equation using different measures of monetary policy, as well as different polynomial lag specifications and different sample periods.

Davis's analysis led him to conclude that "we can't accept the St. Louis equations at face value because neither money nor the total reserve base may be sufficiently exogenous" (p. 126). The only recourse, he suggested, is to build a structural model (like the FRB-MIT model) and reject the reduced-form approach used by AJ. The onus for monetarists, he implied, was to put their ideas into a structural model that details the transmission mechanism of monetary policy.

The controversy generated by the appearance of AJ marked an abrupt change in the "monetary versus fiscal policy" debate. Despite criticism of the AJ study, the earlier view that business cycle evidence relating money and income was "the province of an obscure sect with headquarters in Chicago" (Davis, 1969, p. 119) was changed by their results. Monetary aggregates now were considered plausible alternatives to interest rates and fiscal policy as tools for short-run economic stabilization.

\section{Darryl Francis and the Andersen- Jordan Results}

While the technical analysis, criticism, and responses of the AJ equation took place in both System and academic publications, its policy implications were being disseminated in public forums. Darryl Francis, the president of the St. Louis Bank, used the AJ results to promote the role

\footnotetext{
${ }^{22}$ Reviews include Meyer and Rasche (1980), Batten and Thornton (1986), McCallum (1986), and Brunner (1986).

${ }^{23}$ DeLeeuw, then a Senior Staff Member at the Urban Institute, had been the Chief of the Special Studies Section, Division of Research and Statistics at the Board of Governors and a principal in the design and development of the FRB-MIT model. Kalchbrenner was an economist in the Special Studies Section.
} 
of monetary aggregates in setting stabilization policy. Francis (1968, p. 8) rejected the use of fiscal actions as a tool for stabilization, arguing that "monetary actions are a major determinant of short-run movements in total spending." He also rejected the common view that interest rates and bank credit reflect accurately the stance of monetary policy. Francis (1968) argued that "movements in interest rates should be viewed no differently than movements in commodity prices" (p. 8). Instead, Francis pushed for the "primary and consistent use of monetary aggregates" in setting policy, noting that "all of these aggregates can be rather precisely controlled by monetary authorities" (p. 8). This approach would serve the dual purpose of holding the authorities accountable for their actions and instituting "scientific methodology and modern quantitative analysis" to monetary policy (p. 7).

At an FOMC meeting on February 4, 1969, Francis reviewed how the Committee had been misled by the behavior of interest rates and bank credit:

For about four years ... the Committee had been led into unintended inflationary monetary expansion while following interest rate, net [free] reserves, and bank credit objectives ... If the Committee meant business now, it should try some other guides. Not only could the old guides lead to further inflation as long as demands for credit continued to rise, but when and if contrary trends set in they could lead to an undue contraction of total spending.

Francis also made clear his preferred policy guides: "He urged the Committee to give some evidence that it was exercising restraint by limiting the growth of bank reserves, the monetary base, and the narrow measure of money supply" (FOMC Minutes, February 4, 1969, p. 47).

Francis believed strongly that inflation was the consequence of excessive monetary growth, and that the Fed had erred in pursuing policies that resulted in accelerating growth of the monetary aggregates. In essence, Francis attacked the dominant view that policy should be aimed at stabilizing short-run variation in economic activity, as reflected in the unemployment rate, at the expense of higher inflation. At an FOMC meeting on May 11, 1971, Francis reviewed the course of monetary policy and inflation over the previous 20 years:

During the ten-year period ending in late 1962 , money grew at an average annual rate of 1.5 per cent ... With the economic sluggishness of the early 1960's ... monetary stimulation was increased, and money rose at a 3.5 per cent average annual rate from late 1962 to the end of 1966 ... [T] hat rate of monetary expansion resulted in a gradual increase in inflation to a 3 per cent rate. Following the credit crunch of 1966 money growth was again accelerated, producing a 6.3 per cent average annual rate from early 1967 to the present ... [A] 6 per cent trend rate of monetary expansion implied a sustained 4 per cent rate of inflation. In each case ... the rate of growth in money was accelerated in order to overcome weakness in the economy. Despite those progressively more stimulative monetary actions, the rate of unemployment had averaged about the same whether the trend growth of money was 6 per cent, 3.5 per cent, or 1.5 per cent. The trend growth had had its chief impact on prices, whereas fluctuations around the trend had had the greatest impact on production and employment. (FOMC Minutes, May 11, 1971, pp. 57-58)

Francis's perspective reflected his monetarist outlook: He argued that inflation is primarily determined by the rate of growth of the money stock and that, in the long run, real output growth and the unemployment rate are unaffected by monetary policy. In other words, the long run Phillips curve is vertical. ${ }^{24}$ Francis also argued that while monetary policy has no effect on real growth or employment in the long run, fluctuations in monetary growth could have substantial effects on these variables in the short-run. He used the Andersen and Jordan (1968) results, and those of other Bank economists, to support his claim.

\footnotetext{
24 The distinction between short- and long-run Phillips curves was formalized by Friedman (1968) and Phelps (1967).
} 
Although some members of the Committee shared Francis's views, the chairman and a majority of others did not. In one of the most frank declarations of the opposing view, Chairman William McChesney Martin stated at the October 7, 1969, FOMC meeting that he "did not accept the monetarist's position regarding the critical importance of the specific rate of change in the money supply. In particular, he did not agree that the consequences of deviating significantly from some preferred rate for a period of time would be as disastrous as the monetarists believed" (1969, p. 1100). Board economists Gramley and Chase (1965, p. 1403) went even farther, arguing, "there is little doubt that such a simple rule [based on changes in the money stock] for appraisal of central bank operations is no longer appropriate." 25

Francis cited Federal Reserve Bank of St. Louis research often and at least once entered St. Louis staff forecasts of real output and inflation under alternative money stock growth rates into the formal record of FOMC deliberations. His first recorded reference came at the December 17, 1968, meeting when he discussed "a recent study done at the St. Louis Reserve Bank [which] indicated that with the existing stance of fiscal policy, if money continued to grow at a 6 per cent annual rate throughout the coming year, gross national product would rise at an excessive 8 per cent annual rate" (FOMC Minutes, December 17, 1968, p. 54).

Francis's discussion illustrates that St. Louis Fed officials (and monetarists in general) had begun to actively engage the prevailing wisdom on its own short-run grounds. The AJ results, in effect, provided a platform by which monetarist policy prescriptions, oriented to the behavior of the monetary aggregates, could be discussed in terms of short-run stabilization issues. With one eye cocked to the longer-term inflationary effects of policy, something that the conventional view did not provide, monetarists could also discuss the short-run effects of monetary policy.

Francis's use in FOMC meetings of research conducted by St. Louis Fed economists illustrates how the Fed's decentralized organizational structure can affect policy deliberations. The participation of Federal Reserve Bank presidents in monetary policymaking provides an outlet for alternative perspectives to be heard, including direct criticism of System policy. In addition to bringing the research findings of his staff to FOMC delibera- tions, Francis also promoted St. Louis Fed research in his numerous public appearances. Citing "forthcoming articles," Francis often talked about lags in the impact of monetary policy and how they made attempts to "fine tune" a balance between inflation and unemployment difficult, if not impossible. ${ }^{26}$ Even so, the behavior of the economy in the late 1960s gave credence to the claim that nominal spending responded, albeit with a lag, more to changes in money supply growth than to fiscal policy. The "mini-recession" of 1966 and the failure of tax increases in 1968 to halt the upward march of inflation seemed to support the efficacy of monetary over fiscal policy. While some of his FOMC colleagues had urged tighter fiscal policy to stem inflation in 1968, and supported the temporary tax increase that had been enacted, Francis contended that the tax increase was unlikely to have a significant effect on economic activity. ${ }^{27}$ As Francis predicted, the temporary fiscal measures adopted in 1968 had minimal impact on economic activity.

\section{THE ST. LOUIS MODEL: MONETARISM FOR THE SHORT-RUN}

The predictive success of the St. Louis (AJ) equation and the apparent failure of fiscal policy to stem the inflation of the late 1960s gave monetarists credibility in policy discussions. The behavior of the money stock began to get more consid-

\footnotetext{
${ }^{25}$ Gramley recalls the policy debates this way: “. . . if the Federal Reserve had appreciated how serious the inflationary problem was going to become, they would have paid more attention to the growth of the monetary aggregates and relied less on money market conditions ... if you weren't worried too much about long-run inflation you were inclined therefore not to pay sufficient attention to what was happening to those aggregates" (quoted in Mayer, 1995, pp. 7-8).

${ }^{26}$ For example, at an FOMC meeting on March 9, 1971, he noted that "In the past the System had, on occasion, persisted in a policy course too long. Knowledge of current developments in the economy was available only with a delay, and the effects of monetary actions on spending, production, prices and employment continued for months" (FOMC Minutes, March 9, 1971, p. 66).

27 As Francis summarized his position before the FOMC, "Over the past year the System had aggressively advocated fiscal restraint as a necessity to rational stabilization policy. Yet now that such restraint appeared likely, there seemed to be growing fear of its destabilizing impact. [He] did not share those views . . . Those fiscal measures were generally expected to be temporary, and thus much of the tax burden on consumers would probably come from reduced saving and much of the burden on corporations would probably come from increased borrowing ... The tax measure, because of its temporary nature, might actually cause some acceleration of investment spending" (FOMC Minutes, June 18, 1968, pp. 87-88).
} 
eration in the setting of stabilization policy. ${ }^{28}$ But some observers, even Homer Jones, the St. Louis Bank's research director when the St. Louis model was developed, sounded a note of caution:

Our own econometric studies at St. Louis have long indicated strong, roughly predictable, relations between monetary action, intentional or unintentional, and the course of the economy ... does this mean we can expect to engage usefully in active monetary management in the future? ... I . . conclude that we cannot in the near future engage intelligently in short-run manipulative monetary management. (1970, p.15, emphasis added)

Darryl Francis also warned against using monetary policy to fine-tune economic activity. The success of the AJ equation and the building empirical evidence in support of monetarist views, however, led to a greater focus on the short-run. In his retrospective of the equation's development and use, Jordan (1986, p. 8) notes that "The [AJ] article's impact on economic policymaking would have been more favorable had it not led to an increased reliance on monetary over fiscal policy, but had it instead contributed to a general deemphasis of fine-tuning attempts by policymakers."

The increasingly short-run emphasis undoubtedly reflected, in part, the natural focus of policymaking at the central bank. Dewey Daane, a Federal Reserve governor, noted that the FOMC was "always concentrating on what's the immediate problem over the next four to six weeks and not really thinking in terms of long-run forecasts and inflation" (quoted in Mayer, 1995, p. 16). Governor Andrew Brimmer's recollection corroborates this view, noting that there was "clearly a short-term horizon. [Chairman] Martin put a lot of emphasis on the long run, but that was unusual" (quoted in Mayer, 1995, p. 4).

In April 1970, the Federal Reserve Bank of St. Louis published "A Monetarist Model for Economic Stabilization," by Andersen and Carlson (hereafter, AC). The AC, or "St. Louis" model as it has become known, reflected the latest stage in the development of an empirical model of monetarist propositions and expanded the on-going debate over the role of money in determining aggregate spending and inflation in an important way. Unlike the large-scale macroeconometric models being developed elsewhere, the St. Louis model built upon previous research at the Bank in which the money stock is the central focus of stabilization policy.

The original St. Louis model consisted of eight equations, only four of which were estimated: the total spending equation - the AJ equation, a price equation, an equation for the long-term interest rate, and an unemployment equation. The remaining equations are definitions. ${ }^{29}$ The interest rate equation, based on earlier work by Yohe and Karnosky (1969), reflected the view that interest rates are determined by past inflation and past changes in money growth. The unemployment equation was essentially that developed by Okun (1962). The price equation rejected the typical wage-price markup approach popular at the time. Instead, AC specified the change in the price level as a function of demand pressures and anticipated price changes.

The St. Louis model is "monetarist" in that the money stock is treated as exogenous and its effect on total spending is central to the workings of the model. ${ }^{30}$ As AC state:

The change in total spending is combined with potential (full employment) output to provide a measure of demand pressure. Anticipated price change, which depends on past price changes, is combined with demand pressure to determine the change in the price level. The total spending identity enables the change in output to be determined, given the change in total spending and the change in prices. (p.10)

\footnotetext{
28 In reviewing the discussion of monetary policy at a recent conference, Friedman wrote to Homer Jones in July 1969 that "I, too, have been very much impressed with the evidence that a new day has dawned . . . I almost fell over when he [Board Governor Dewey Daane] started talking about the importance of paying attention to monetary aggregates" (Friedman Papers, Box 28, Folder 36).

29 The original model is summarized in the Appendix. Carlson (1986) provides a comparison of the original version and the then "current" version which reflects modifications over the intervening years.

30 AC determine real output as a residual; that is, output is determined as the difference between total spending and the price level. As they note, "This method of determining the change in total spending and its division between output change and price change differs from most econometric models. A standard practice in econometric model building is to determine output and prices separately, then combine them to determine total spending" (p.10).
} 
The structure of the model meant that for a given change in the money supply or government expenditures, one could solve for changes in total spending, prices, real output, the unemployment rate, and interest rates. The model was simple in comparison with the complex structural models used by the Board staff and elsewhere. For example, whereas the Wharton model, a representative Keynesian structural model, had 43 exogenous variables, the St. Louis model had just three. The model also omitted details about specific sectors for the simplicity of determining the impact of a change in money growth on the economy broadly. This development fit nicely with the view of many monetarists that "the Federal Reserve should be concerned with the aggregate effects of policy, and should leave the allocative details to the operation of the market" (Francis 1973, p. 9). ${ }^{31}$ As Carlson (1986, p. 18) recollects the development of the model,

we wanted a model that was small enough that the interrelationships among the varables could be understood easily ... We were not concerned about respecifying behavioral equations ... [and] we wanted to capture empirical relationships between a relatively few key macroeconomic variables that were implicitly grounded in economic theory.

AC state explicitly that their statistical analysis is used "to estimate the response of output and prices to monetary and fiscal actions, not to test a hypothesized structure" (pp. 10-11). ${ }^{32}$ The original estimates appeared to support the monetarist view of the world: an increase in the money supply leads first to an immediate increase in nominal spending and real output, and only after prices adjust to the higher demand pressure does the price level rise to stifle the increase in real output.

\section{Using the Model for Short-Run Analysis}

Andersen and Carlson used the St. Louis model to simulate nominal spending, real output, inflation, and the unemployment rate for different hypothesized growth paths for money. They also compared their monetarist model's forecasting ability with that of the Wharton model during 1963-64, a period that included a major fiscal action-the tax cut of 1964 . How would the St.
Louis model, in which fiscal policy plays a minor role, fare in comparison with the Wharton model in which fiscal policy has a much larger role than money? The St. Louis model's simulations were better (i.e., produced lower root-mean-squared errors) than the Wharton model for nominal GNP and the unemployment rate, about the same for real GNP, and worse for the price level. The upshot was that this small, monetarist-oriented model could prove as valuable to policymakers as the large-scale Keynesian models then in use. Importantly, it seemed to demonstrate the usefulness of a small monetarist model for current analysis. As AC state, "The purpose of the following statistical section is to estimate the response of output and prices to monetary and fiscal actions, not to test a hypothesized structure. The focus is on the response in the short run-periods of two or three years - but the long-run properties also are examined" (1970, pp. 10-11, emphasis added).

The success of the St. Louis model was important to monetarism's growing impact on policy discussions. It also appeared soon after Friedman (1968) and Phelps (1967) provided theoretical models in which the popular Phillips curve tradeoff between inflation and unemployment (and, hence, real output growth) was shown to be transitory. The Phillips curve, a version of which appears in the St. Louis model, was a critical component of most Keynesian macro-models of the time. The results of AC provided an empirical demonstration that although expansionary monetary policy might produce a short-run increase in real output growth and a dip in the unemployment rate, these effects would vanish over time as inflation increased and unemployment and output growth returned to their "natural" or trend rates.

The St. Louis model enabled monetarists to produce short-run forecasts of alternative policy scenarios, thereby putting them on similar footing

\footnotetext{
31 A recurrent theme in discussions about the role of policy was the recognition that policy actions sometimes affected certain industries-most notably housing-more than others. Such attention was disruptive to the working of market forces, Francis believed. He noted that "Regulation of interest rates paid by commercial banks and thrift institutions unduly disrupts the allocation function of markets. Furthermore, excessive concern for the well-being of these institutions and the housing industry has caused monetary authorities to expand the money stock at a rapid rate during much of the current inflationary period" (1968, p. 9).

32 Francis (1973, p. 8) makes the point that "The bewildering struggles that occur between model builders over specification errors, structural versus reduced-form models, recursive versus non-recursive systems, etc., are meaningless to most policymakers."
} 
with other mainstream economists, both in and outside of the Federal Reserve System. Dewald $(1988$, p. 6) contends that with the development of the St. Louis model, "monetarism was widely interpreted as providing an alternative to short-run Keynesian model forecasts." The St. Louis model, though grounded in the long-run conditions of the Quantity Theory, increasingly was used to counter the short-run policy prescriptions coming from the larger structural models in use at the Board. The St. Louis model, estimated using quarterly observations and with the money stock - not interest rates-as the policy instrument, led many observers to conclude that the money stock could be an effective tool for economic stabilization.

The shifting emphasis at the St. Louis Bank toward short-run policy analysis can be found in comments of participants in the model's development. Carlson (1972, p. 25) warned against using the model for anything but interpreting the "general time path" of important macroeconomic variables. Even so, analysis of the short-run impact of alternative policies is precisely what the model came to be used for. His own admonition aside, Carlson (1972, p. 20) noted that the model "presents a set of simulations using alternative steady growth rates which can aid in assessing the economic impact over several quarters of different trend growth rates of money" (emphasis added). In keeping with this view, his analysis of the model's performance was based on a six-quarter horizon, hardly the long run used by early monetarist studies. But such a use for the model appeared justified by the empirical results: "the model succeeded in roughing out the average time paths of total spending, real product, prices, unemployment, and interest rates during the period from late 1969 to mid-1971" (Carlson, 1972, p. 26, emphasis added).

The model's success as a forecast tool gave support to monetarist calls for a policy aimed at stable money growth. In reviewing the debate over stabilization policy, Andersen (1973, p. 3) summarized the model's success at forecasting real output and inflation, stating that "The key proposition is that changes in money dominate other short-run influences on output and other long-run influences on the price level and nominal aggregate demand" (emphasis added). The St. Louis model suggested that stable money growth would lessen any monetary-induced instability in the real economy while promoting price stability in the long run.
Research from St. Louis continued to provide a long-term, inflation-oriented perspective on monetary policy actions, reflecting rising inflation of the early 1970s. At the same time, the Review contained numerous studies, often authored by Andersen or Keran, of the short-run response of the economy to changes in the growth of the monetary aggregates. The allure of short-run analysis perhaps is best illustrated by Carlson's (1975) estimation of the St. Louis equation using monthly data. Replacing nominal GNP with personal income, Carlson found that the lag from changes in the growth of money to nominal income was completed in about one year, similar to that found by AJ, though slower than reported in other studies. ${ }^{33}$ The implication of this finding was clear: Carlson (1975, p. 17) suggests that the "Use of monthly data thus appears to carry the potential for evaluating the thrust of monetary and fiscal actions before quarterly data on GNP become available."

In the late 1960 s, public interest in monetarism rose as inflation continued to increase. Monetarists were called upon by the incoming Nixon administration for advice. Milton Friedman wrote a regular column for Newsweek alongside one by Paul Samuelson, who had been a leading advisor to the previous two administrations and a leading architect of the so-called New Economics. Increased attention, however, brought more strident criticism. By 1972 there already were claims that monetarism had "failed." For example, in his Newsweek column of August 2, 1971, Samuelson objected to the monetarist claim that rapid money growth in 1971 would subsequently lead to faster nominal GNP growth. He suggested that "the forecasting ability of monetarism is selling at a huge discount on the markets of informed opinion" (Samuelson 1971, p. 70) and that the "pseudopositivism which prevails among monetarists. . . [is] still another reason why the peculiar tenets of monetarism have to be rejected" (quoted in Francis, 1972, p. 32).

Members of the Board of Governors also criticized the policy advice of monetarists. For example, Andrew Brimmer, echoing arguments made during the previous two decades, rejected any policy based on control of the monetary aggregates: "I am convinced that it would be a disastrous

\footnotetext{
33 Another example of attempts to model the short-run effects of money on the economy is Laffer and Ransom (1971). Unlike the St. Louis results, Laffer and Ransom report that monetary actions lead to an immediate and permanent effect on the level of GNP.
} 
error for the Federal Reserve to try to conduct monetary policy on the basis of a few simple rules governing the rate of expansion of the money supply" (1972, p. 351).

Francis (1972, p. 32) considered such attacks "strident," "doctrinaire," and "no more precise than in the past." He answered these criticisms by pointing to the St. Louis model's ability to forecast economic activity over the short-run. He compared income, inflation, and unemployment predictions for 1969,1970 , and 1971 derived from the St. Louis model to those of the consensus Livingston forecasts. The overall forecasting ability of the St. Louis model compared favorably with the consensus forecasts. Although Francis maintained that policy should take a longer-term view to be effective, he focused on a few years of forecasting results to justify applying the model to shorter time horizons.

\section{Refining the Model}

As the 1970s progressed, neither Keynesian models based on the Phillips curve and interest rates, nor simple monetarist models based on growth of the money stock, successfully forecast the rapid inflation and higher unemployment that actually occurred. Monetarists faced the task of explaining why inflation had increased so dramatically without a similar-sized increase in money stock growth. Monetarists, including St. Louis Fed officials, responded that their critics had confused changes in the aggregate price level, which are caused by monetary policy, with changes in relative prices brought on by special factors. Francis presented the Bank's position in a series of speeches in 1974. He pointed out that the increase in inflation was due largely to an increase in money growth over the preceding few years. Any inflation over and above the underlying monetary growth rate was caused by the removal of wage and price controls and the increase in oil prices by the OPEC nations. ${ }^{34}$

St. Louis Fed economists soon integrated such special factors in their studies. Karnosky (1976) demonstrated that money growth continued to explain longer-term movements of inflation once the oil price shock effects were accounted for. Rasche and Tatom (1977) extended this idea in their examination of the effects of supply shocks on the economy and how they could distort the statistical relationship between money and income in the short-run. Although aspects of these works were criticized, they suggested that the money supply remained useful for stabilization purposes.

\section{The Breakdown of the Monetarist Rule}

Kane (1990) observes that as the rate of inflation continued to increase over the 1970s, the growing weight of evidence supporting the monetarist position pushed the FOMC to incorporate money stock growth into their policy deliberations and evaluations. This was quite a change from their position of a decade earlier when "they treated monetarism as an eccentric and quasi-religious belief system that no responsible macroeconomist or public official could possibly take seriously"(p. 292).

Monetarism as a policy approach, however, had a relatively short stay in the limelight. In October 1979, the Federal Reserve adopted new operating procedures that it claimed would enhance its control of the money stock. Highly restrictive policies also were enacted to reduce inflation, which had reached double-digit levels. Although inflation eventually declined significant$1 y$, the more immediate effect was to send the economy into the deepest recession of the postwar period. Critics associated the policy with monetarism, referring to the policy as the Fed's "monetarist experiment," and this perception contributed to the widespread discounting of monetarism as a viable policy option. Monetarists protested that the Fed had not, in fact, adopted their preferred policy of slow and steady money growth. Rather, they noted, the variability of money growth actually increased after 1979 and gave rise to increased fluctuations in real economic activity without any appreciable short-run effect on inflation. ${ }^{35}$

\footnotetext{
${ }^{34}$ Francis argued similarly in FOMC deliberations. At a meeting on January 22, 1974, for example, Francis contended that "the actual and prospective slowdown in economic activity resulted wholly from capacity, supply, and price-distorting constraints and not from a weakening in demand. Therefore, to ease [monetary] policy and allow a faster rate of monetary growth would be to increase inflationary pressures without expanding real output or reducing unemployment” (FOMC Minutes, January 22, 1974, p. 102).

35 Batten and Stone (1983) provide an overview of the issues and evidence in support of the monetarist position. For contrasting assessments of this episode, see B. Friedman (1984) and M. Friedman (1984). Charles Schultz, Chairman of the Council of Economic Advisors from 1977-81, considered the monetarist experiment in this light: "What monetarism really is for the Fed (and I'm morally certain this is what Volcker thinks, too) a political cover. They're not monetarists, but it allowed them to do what they could never have done ... They could never have done what needed to be done if it looked as if they were the ones raising interest rates, when they were targeting interest rates, per se. But with fixed monetary targets they could just say, 'Who, us?'” (quoted in Hargrove and Morely, 1984, p. 486).
} 
Regardless of whether the Fed had in fact adopted a monetarist policy in 1979, large, volatile movements in velocity began to erode professional support for monetarist policies. Inflation and attendant increases in market interest rates encouraged financial innovations that gave consumers more options for holding liquid balances. This, in turn, spurred regulatory changes that produced sharp changes in the relative demands for liquid financial assets. At the same time, the Fed's abrupt tightening brought a sharp decline in the rate of inflation, which probably contributed to a reversal of the upward trend in velocity that had characterized the previous three decades. ${ }^{36}$ Asset demand shifts and uncertainty about the Fed's commitment to a new path for inflation probably explain why the velocity of traditional measures of the money stock, especially the narrow measures, such as M1, favored by officials of the Federal Reserve Bank of St. Louis, began to move erratically. Stable velocity was crucial for the reduced-form models used at St. Louis to hold. If the path of velocity changed unpredictably, then the predictions of the St. Louis equation and model could be unreliable. ${ }^{37}$ As velocity began to deviate seriously and continuously from its previously stable path, monetarist policy prescriptions became increasingly suspect.

As shown in Figure 1, the velocity of $\mathrm{M} 1$ - the monetary aggregate used in the St. Louis modelmaintained a fairly steady upward climb during the 1960s and 1970s. During the 1980s, however, M1 velocity deviated considerably from its previous path. M1 velocity appeared to become "unstable," thus justifying critics' opposition to monetary targeting. ${ }^{38}$

As M1 velocity deviated further from its historic trend, St. Louis Fed researchers devoted increasing effort to understanding velocity and modifying their forecasting model. Meyer and Varvares (1981), for example, made two modifications: one modification was to model the rate of inflation as a direct outcome of money growth and oil price shocks; the other modification incorporated a new Phillips curve relation. Other St. Louis Fed studies researched the lag between money and prices (Carlson, 1980), the effects of fiscal policy (Hafer, 1982), and the longer-run consequences of policy (Carlson and Hein, 1983). These studies all concluded that the reduced-form approach continued to be a reasonable way of modeling the impact of monetary policy on the

\section{Figure 1}

\section{Velocity of Money (M1)}

Quarterly Data, 1960 Through 1999

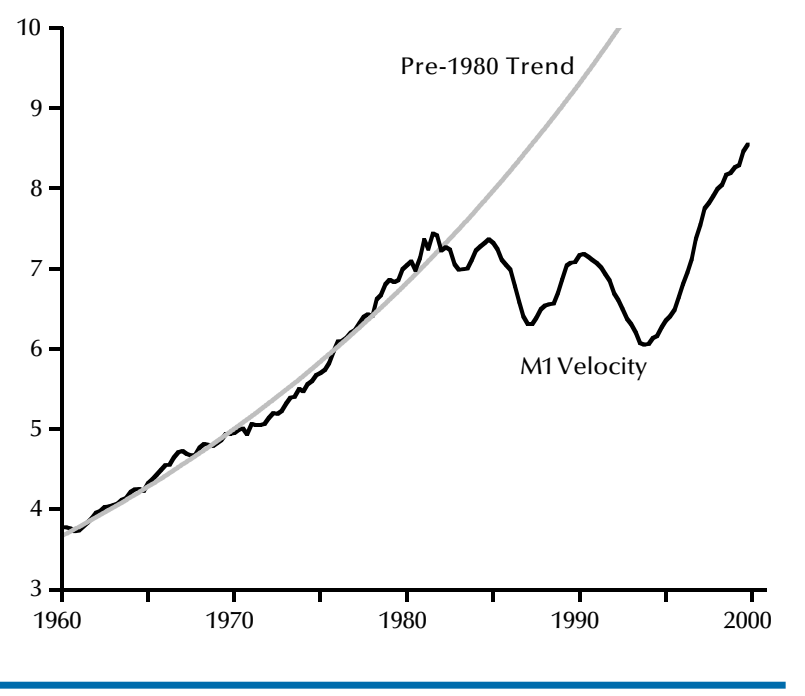

economy, and early success at improving model forecasts encouraged further research along the same lines. But, because the shift in velocity had occurred only recently, and therefore affected only a limited number of observations used in the estimation of the model, these papers largely ignored the potential effects of the shift. Indeed, even Carlson's (1986) version of the model, one that made minor revisions that recognized the

\footnotetext{
${ }^{36}$ Gavin and Dewald (1989) show that disinflation leads to a reduction in velocity once the public comes to expect that a new trend growth rate of money and the price level have been established.

37 This potential problem was already known. For example, Rasche (1972) noted that the successful forecasting ability of the St. Louis equation was, in part, based on the small interest elasticity of the money demand function. As he states (p. 31): "if the short-run interest elasticity of the money demand function is very small, then an estimated equation omitting this term [the interest rate] would most likely produce a credible forecasting record" (emphasis in original). In some sense, the constant term in equation (1) is the empirical representation of velocity. Financial innovations altered the underlying short-run interest elasticity of money demand and adversely affected the equation's forecasting ability. Because no changes along these lines were made to the model, its forecasts began to stray. More recent investigations of the behavior of velocity include Stone and Thornton (1987), Rasche (1993), Hoffman and Rasche (1996), and Laurent (1999).

38 Monetarists had long divided over whether a narrow aggregate, such as the monetary base or M1, or a broader aggregate, such as M2 or M3, was a preferable target for monetary policy. St. Louis Fed officials advocated M1, while Milton Friedman favored M2. When M1 velocity began to deviate from its trend in the early 1980 s, M2 velocity remained relatively stable. By the early 1990s, however, M2 velocity also had deviated substantially from its longrun trend.
} 
impact of energy prices, wage and price controls, and several other technical changes, continued to fit the data reasonably well. Thus, for a time, monetarists continued to argue that nominal income growth reflected changes in money growth over short periods and that inflation reflected money growth over longer periods, even during this turbulent time. As the 1980s progressed, however, continued instability of velocity caused all but the most diehard supporters to abandon short-run monetary aggregate targets.

\section{LESSONS FROM THE ST. LOUIS EXPERIENCE}

The development and decline of the St. Louis monetarist model as a guide to short-run stabilization policy is not unlike the evolution of stabilization policies designed to exploit a tradeoff between inflation and unemployment. Policies based on the Phillips curve arose from an apparently robust empirical relationship between inflation and unemployment observed in macroeconomic data. As discussed in King and Watson (1994), the negative correlation between the variables in the short-run suggested the presence of a long-run structural relationship that could be exploited for policy purposes. Attempts to manipulate interest rates to increase the growth of real output and employment above potential, however, gave rise to what has been called "the great inflation" in the United States, a period encompassing the 1960 s and 1970s. ${ }^{39}$

Over the 1970s, as inflation and unemployment rose simultaneously, monetarists gained a stronger voice in monetary policy debates as the long-run relations among money, prices, and nominal income seemed to hold even in the short-run. Due in part to work at the Federal Reserve Bank of St. Louis, Woodford (forthcoming, p. 18) suggests that "the monetarist viewpoint had become the new orthodoxy by the mid-1970s."

The St. Louis Bank and its officials had special prominence because they provided an avenue for monetarist research and views to potentially influence policy deliberations. To be influential, however, monetarists had to offer a viable policy for the short-run-a policy that could be discussed and voted on at meetings some six weeks apart. The success of the St. Louis model at forecasting output, nominal income, and prices over such short horizons during the 1970s convinced St.
Louis Fed officials that they could credibly advocate a monetarist stabilization policy for the short-run.

The Federal Reserve took a step toward monetary aggregate targeting in October 1979, when new procedures were implemented to better control the money stock with the goal of reducing inflation. The targeting of monetary aggregates was largely abandoned in 1982, however, when velocity, particularly of $\mathrm{M} 1$ - the narrow aggregate favored by St. Louis Fed officials-proved too erratic.

Deregulation, other institutional changes, and uncertainty about the Fed's commitment to disinflation probably explain much of the unstable behavior of velocity in the 1980s. The Depository Institution Deregulation and Monetary Control Act of 1980 (DIDMCA) instituted a six-year process ending the prohibition of interest payments on transaction accounts at commercial banks and deregulating rates on other accounts. These changes, and various financial innovations, were followed by volatile flows between classes of financial assets that altered the empirical relationships between national income and monetary aggregates. Monetary aggregates quickly lost favor as short-run policy targets when movements in velocity became difficult to explain or predict. In essence, changes in the structure of the economy altered the short-run relationships between traditional monetary aggregates and policy objectives. Monetarist models, including the St. Louis model, were not equipped to handle such changes, and their forecasting performance suffered as a result.

Typical macroeconomic models of the 1970s, including the St. Louis model, also were not equipped to deal with the so-called "Lucas Critique." Lucas (1976) demonstrated that coefficient estimates of typical forecasting models are unlikely to be stable across policy regimes. As individuals learn about and modify their behavior in response to a change in regime, empirical relationships among macroeconomic variables may change. Consequently, economic projections based on estimation of a model over one regime may not be valid for a different regime. For example, the close short-run correlations among money, output, and prices observed during the 1960s and 1970s under a regime characterized by interest rate targeting would not necessarily have been so close in a regime of monetary aggregate

\footnotetext{
${ }^{39}$ For alternative views of this period, see DeLong (1997), Mayer (1999), Sargent (1999), Taylor (1999), or Wheelock (1998).
} 
targeting. 40

The search for robust empirical relationships across different regimes has shown that money, nominal income, and inflation remain closely linked in the long run (Dewald, 1998; Dwyer and Hafer, 1999; Lucas, 1996; Rolnick and Weber, 1997). There also is some evidence that the linkages between money and economic activity are robust even at relatively short-run frequencies. ${ }^{41}$ Monetary aggregates again may prove useful for economic forecasting or as guides for conducting monetary policy. Experience has shown, however, that empirical relationships between policy variables and goals can change, sometimes unpredictably. The experience with the monetarist rule as developed at the St. Louis Fed councils against overconfidence in our ability to identify infallible rules for conducting short-run stabilization policy.

\section{REFERENCES}

Andersen, Leonall C. "Federal Reserve Defensive Operations and Short-Run Control of the Money Stock." Journal of Political Economy, March/April 1968, p. 275-88.

"The State of the Monetarist Debate." Federal Reserve Bank of St. Louis Review, September 1973, 55(9), pp. 2-8.

and Jordan, Jerry L. "Monetary and Fiscal Actions: A Test of Their Relative Importance in Economic Stabilization [reprint]." Federal Reserve Bank of St. Louis Review, October 1986, 68(8), pp. 29-44.

and "Monetary and

Fiscal Actions: A Test of Their Relative Importance in Economic Stabilization." Federal Reserve Bank of St. Louis Review, November 1968, 50(11), pp. 11-24.

and Carlson, Keith M. "A Monetarist

Model for Economic Stabilization.” Federal Reserve Bank of St. Louis Review, April 1970, 52(4), pp. 7-25.

Ando, Albert; Brown, E. Cary; Solow, Robert M. and Kareken, John. "Lags in Fiscal and Monetary Policy," in Stabilization Policies: Commission on Money and Credit. Englewood Cliffs, NJ: Prentice Hall, 1963, pp. 1-164.

Ando, Albert and Modigliani, Franco. “The Relative Stability of Monetary Velocity and the Investment Multiplier." American Economic Review, September 1965, pp. 693-728.

Angell, James W. "Appropriate Monetary Policies and Operations in the United States Today." Review of Economics and Statistics, August 1960, pp. 247-52.
Barro, Robert J. "Inflation and Growth.” Federal Reserve Bank of St. Louis Review, May/June 1996, 78(3), pp. 153-69.

Batten, Dallas S. and Stone, Courtenay C. "Are Monetarists an Endangered Species?" Federal Reserve Bank of St. Louis Review, May 1983, 65(5), pp. 5-16.

and Thornton, Daniel L. "The Monetary-Fiscal Policy Debate and the Andersen-Jordan Equation." Federal Reserve Bank of St. Louis Review, October 1986, 68(8), pp. 9-17.

Brimmer, Andrew F. “The Political Economy of Money: Evolution and Impact of Monetarism in the Federal Reserve System.” American Economic Review, May 1972, pp. 344-52.

Bronfenbrenner, Martin and Holzman, Franklin D. "Survey of Inflation Theory.” American Economic Review, September 1963, 52, pp. 593-661.

Brunner, Karl. "Fiscal Policy in Macro Theory: A Survey and Evaluation," in R.W. Hafer, ed. The Monetary Versus Fiscal Policy Debate: Lessons from Two Decades. Totowa, NJ: Rowman and Allanheld, 1986, pp. 33-116.

and Balbach, Anatol B. "An Evaluation

of Two Types of Monetary Theories." Proceedings of the Thirty-Fourth Annual Conference of the Western Economic Association, 1959, pp. 78-84.

Burger, Albert E. The Money Supply Process. Belmont, CA: Wadsworth Publishing Co., 1971.

40 The monetarist experience, in which proponents sought to replace one regime with another, contrasts with Taylor's (1993) proposal for the Fed to continue the policy rule that he found described recent policy well. Researchers have, however, questioned how well the Taylor rule actually represents Fed policy. Orphanides (1997), for example, shows that a Taylor rule derived from real-time data produces a federal funds rate path over the past decade that is quite different from that found using revised data. Kozicki (1999) shows that Taylor rule predictions are not robust to differences in meas ures of inflation, the output gap, the real interest rate, and to different parameterizations. Finally, Hetzel (2000) argues that use of the Taylor rule within an activist model of monetary policy will mislead policymakers as they attempt to control inflation.

41 Dwyer and Hafer $(1988,1999)$ find that for a large cross-section of countries the correlation between money growth and nominal income is close to unity even over short time horizons. Similarly, based on estimates of a small VAR model with quarterly U.S. data, Dwyer (1998) concludes that the link between money and nominal income may be much closer than some have claimed. Finally, using a recursive estimate of equilibrium M2 velocity, Orphanides and Porter (2000) find that monetary aggregate-based forecasts of inflation for the 1990s are quite accurate. 
Carlson, Keith M. "Projecting with the St. Louis Model: A Progress Report.” Federal Reserve Bank of St. Louis Review, February 1972, 54(2), pp. 20-26.

"The St. Louis Equation and Monthly Data." Federal Reserve Bank of St. Louis Review, January 1975, 57(1), pp. 14-17.

"Money, Inflation, and Economic Growth: Some Updated Reduced Form Results and Their Implications." Federal Reserve Bank of St. Louis Review, April 1980, 62(4), pp. 13-19.

"A Monetarist Model for Economic Stabilization: Review and Update.” Federal Reserve Bank of St. Louis Review, October 1986, 68(8), pp. 18-28.

and Hein, Scott E. "Four Econometric Models and Monetary Policy: The Longer-Run View.” Federal Reserve Bank of St. Louis Review, January 1983, 65(1), pp. 13-24.

Davis, Richard G. "The Role of the Money Supply in Business Cycles.” Federal Reserve Bank of New York Monthly Review, April 1968, pp. 63-73.

"How Much Does Money Matter?

A Look at Some Recent Evidence.” Federal Reserve Bank of New York Monthly Review, June 1969, pp. 119-31.

DeLeeuw, Frank and Kalchbrenner, John. "Monetary and Fiscal Actions: A Test of Their Relative Importance in Economic Stabilization-Comment.” Federal Reserve Bank of St. Louis Review, April 1969, 51(4), pp. 6-11.

DeLong, J. Bradford. "America's Only Peacetime Inflation: The 1970s," in Christina Romer and David Romer, eds. Reducing Inflation. Chicago: University of Chicago Press, 1997, pp. 247-76.

“The Triumph of Monetarism?" Journal of Economic Perspectives, Winter 2000, pp. 83-94.

DePrano, Michael and Mayer, Thomas. "Tests of the Relative Importance of Autonomous Expenditures and Money." American Economic Review, September 1965, pp. 729-52.

Dewald, William G. "Monetarism is Dead; Long Live the Quantity Theory.” Federal Reserve Bank of St. Louis Review, July/August 1988, 70(3), pp. 3-18.
"Historical U.S. Money Growth, Inflation and Inflation Credibility." Federal Reserve Bank of St. Louis Review, November/December 1998, 70(6), pp. 13-23.

Dwyer, Gerald P. Jr. "Is Money Growth a Leading Indicator of Inflation?" Conference volume from the international conference on The Conduct of Monetary Policy, Taipei, Taiwan, June 1998 (forthcoming).

and Hafer, R.W. "Is Money Irrelevant?" Federal Reserve Bank of St. Louis Review, May/June 1988, 70(3), pp. 3-17.

and "Are Money and Inflation Still Related?" Federal Reserve Bank of Atlanta Economic Review, Second Quarter 1999, pp. 32-43.

Economic Report of the President (various issues).

FOMC Minutes, 1968, 1969, 1970.

Francis, Darryl. "An Approach to Monetary and Fiscal Management." Federal Reserve Bank of St. Louis Review, November 1968, 50(11), pp. 6-10.

"Has Monetarism Failed? The Record Examined." Federal Reserve Bank of St. Louis Review, March 1972, 54(3), pp. 32-38.

"The Usefulness of Applied Econometrics to the Policymaker: An Address." Federal Reserve Bank of St. Louis Review, May 1973, 55(5), pp. 7-10.

Friedman, Benjamin M. "Lessons from the 1979-82 Monetary Policy Experiment." American Economic Review, Papers and Proceedings, May 1984, pp. 382-87.

Friedman, Milton, ed. Studies in the Quantity Theory of Money. Chicago: University of Chicago Press, 1956.

A Program for Monetary Stability. New York: Fordham University Press, 1960.

"The Role of Monetary Policy." American Economic Review, March 1968, pp. 1-17. "Lessons from the 1979-82 Monetary Policy Experiment." American Economic Review, Papers and Proceedings, May 1984, pp. 397-400.

"An Interview with Milton Friedman." Federal Reserve Bank of Minneapolis The Region, June 1992. 
and Meiselman, David. "The Relative Stability of Monetary Velocity and the Investment Multiplier in the United States, 1897-1958," in Stabilization Policies. Englewood Cliffs, NJ: Prentice Hall, 1963, pp. 165-268.

and "Reply to Ando and

Modigliani and to DePrano and Mayer." American Economic Review, September 1965, pp. 753-85.

and Schwartz, Anna J. A Monetary History of the United States, 1867-1960. Princeton: Princeton University Press, 1963.

and Monetary Statistics of the

United States: Estimates, Sources, and Methods. New York: National Bureau of Economic Research, 1970.

and Monetary Trends in the United States and the United Kingdom: Their Relation to Income, Prices, and Interest Rates, 1867-1975. Chicago: University of Chicago Press, 1982

Gavin, William T. and Dewald, William G. "The Effect of Disinflationary Policies on Monetary Velocity." The Cato Journal, Spring/Summer 1989, pp. 149-64.

Gramley, Lyle E. and Chase, Samuel B. Jr. "Time Deposits in Monetary Analysis." Federal Reserve Bulletin, October 1965, pp. 1380-404.

Hafer, R.W. "The Role of Fiscal Policy in the St. Louis Equation.” Federal Reserve Bank of St. Louis Review, January 1982, 64(1), pp. 17-22.

"Against the Tide: Malcolm Bryan and the Introduction of Monetary Aggregate Targets." Federal Reserve Bank of Atlanta Economic Review, First Quarter 1999, pp. 20-37.

Hargrove, Erwin C. and Morely, Samuel A., eds. The President and the Council of Economic Advisors: Interviews with CEA Chairmen. Boulder: Westview Press, 1984.

Harris, Seymour E. "Controversial Issues in Recent Monetary Policy: A Symposium, Introduction and Summary." Review of Economics and Statistics, August 1960, pp. 245-47.

Hansen, Alvin H. "Appropriate Monetary Policy, 1957 1960." Review of Economics and Statistics, August 1960, pp. 255-56.
Hester, Donald D. "Keynes and the Quantity Theory: A Comment on the Friedman-Meiselman CMC Paper." Review of Economics and Statistics, November 1964, pp. 364-68.

Hetzel, Robert L. "The Taylor Rule: Is it a Useful Guide to Understanding Monetary Policy?” Federal Reserve Bank of Richmond Economic Quarterly, Spring 2000, pp. 1-33.

Hoffman, Dennis and Rasche, Robert H. Aggregate Money Demand Functions: Empirical Applications in Cointegrated Systems. Boston: Kluwer Academic Publishers, 1996.

Johnson, Harry G. "Monetary Theory and Policy." American Economic Review, June 1962, pp. 335-84.

"The Keynesian Revolution and the Monetarist Counter-Revolution." American Economic Review, Papers and Proceedings, May 1971, pp. 1-14.

Jones, Homer. "Observations on Stabilization Management." Federal Reserve Bank of St. Louis Review, December 1970, 52(12), pp. 14-19.

Jordan, Jerry L. "The Andersen-Jordan Approach After Nearly 20 Years.” Federal Reserve Bank of St. Louis Review, October 1986, 68(8), pp. 5-8.

Kane, Edward J. "Bureaucratic Self-Interest as an Obstacle to Monetary Reform," in Thomas Mayer, ed. The Political Economy of American Monetary Policy. Cambridge: Cambridge University Press, 1990, pp. 283-98.

Karnosky, Denis S. "The Link Between Money and Prices1971 -76." Federal Reserve Bank of St. Louis Review, June 1976, 58(6), pp. 17-23.

Keran, Michael W. "The Effect of Total Demand on Real Output.” Federal Reserve Bank of St. Louis Review, July 1966, 48(7), pp. 7-12.

King, Robert G. and Watson, Mark W. "The Post-War U.S. Phillips Curve: A Revisionist Econometric History.” Carnegie-Rochester Conference Series on Public Policy, December 1994, pp. 157-219.

Kozicki, Sharon. "How Useful are Taylor Rules for Monetary Policy?" Federal Reserve Bank of Kansas City Economic Review, Second Quarter 1999, pp. 5-33.

Laffer, Arthur B. and Ranson, R. David. "A Formal Model of the Economy." The Journal of Business, July 1971, pp. 247-70. 
Laurent, Robert D. "Is the Demise of M2 Greatly Exaggerated?" Contemporary Economic Policy, October 1999, pp. 492-505.

Lucas, Robert E. Jr. "Econometric Policy Evaluation: A Critique." Carnegie-Rochester Conference Series on Public Policy Vol. 1, The Phillips Curve and Labor Markets, 1976, pp. 19-46.

"Nobel Lecture: Monetary Neutrality." Journal of Political Economy, August 1996, pp. 661-82.

Maisel, Sherman J. Managing the Dollar. New York: WW Norton \& Company, 1973.

Mayer, Thomas. Interviews, Special Collections, General Library, University of California-Davis, 1995.

Monetary Policy and the Great Inflation in the United States: The Federal Reserve and the Failure of Macroeconomic Policy, 1965-1979. Cheltenham, UK: Edward Elgar, 1999.

McCallum, Bennett T. "Monetary Versus Fiscal Policy Effects: A Review of the Debate," in R.W. Hafer, ed. The Monetary Versus Fiscal Policy Debate: Lessons from Two Decades. Totowa, NJ: Rowman \& Allanheld, 1986, pp. 9-32.

Meigs, A. James. "Recent Innovations in the Functions of Banks.” American Economic Review, May 1966, 56, pp. 167-77.

"Campaigning for Monetary Reform: The Federal Reserve Bank of St. Louis in 1959 and 1960.” Journal of Monetary Economics, November 1976, pp. 439-53.

Meltzer, Allan H. "Monetarism: The Issues and the Outcome." Atlantic Economic Journal, March 1998, pp. 8-31.

Meyer, Laurence H. and Rasche, Robert H. "Empirical Evidence on the Effects of Stabilization," in Stabilization Policies: Lessons from the "70s and Implications for the '80s, Proceedings. St. Louis: Center for the Study of American Business and Federal Reserve Bank of St. Louis, 1980, pp. 41-102.

and Varvares, Chris. "A Comparison of the St. Louis Model and Two Variations: Predictive Performance and Policy Implications.” Federal Reserve Bank of St. Louis Review, December 1981, 63(10), pp. 13-25.
Mishkin, Frederic S. "What Should Central Banks Do?" Federal Reserve Bank of St. Louis Review, November/December 2000, 82(6), pp. 1-14.

Okun, Arthur M. "Potential GNP: Its Measurement and Significance." Proceedings of the Business and Economic Statistics Section of the American Statistical Association, 1962, pp. 98-104.

Orphanides, Athanasios. "Monetary Policy Rules Based on Real-Time Data.” FEDS Working Paper 1998:03, Federal Reserve Board of Governors, December 1997.

and Porter, Richard D. " $\mathrm{P} *$ Revisited: MoneyBased Inflation Forecasts with a Changing Equilibrium Velocity." Journal of Economics and Business, January/April 2000, 52(1-2), pp. 87-100.

Perlman, Richard, ed. Inflation: Demand-Pull or Cost-Push? Boston: D.C. Heath, 1965.

Perry, George L. Unemployment, Money Wage Rates, and Inflation. Cambridge, MA: MIT Press, 1966.

Phelps, Edmund S. "Phillips Curves, Expectations of Inflation and Optimal Unemployment Over Time." Economica, August 1967, pp. 254-81.

Phillips, A.W. "The Relation Between Unemployment and the Rate of Change of Money Wage Rates in the United Kingdom, 1861-1957." Economica, November 1958, 25, pp. 283-99.

Rasche, Robert H. "Comments on a Monetarist Approach to Demand Management." Federal Reserve Bank of St. Louis Review, January 1972, 54(1), pp. 26-32.

"Monetary Aggregates, Monetary Policy and Economic Activity." Federal Reserve Bank of St. Louis Review, March/April 1993, 75(2), pp. 1-35.

and Tatom, John A. "The Effects of the New Energy Regime on Economic Capacity, Production and Prices.” Federal Reserve Bank of St. Louis Review, May 1977, 59(5), pp. 2-12.

Rolnick, Arthur J. and Weber, Warren E. "Money, Inflation, and Output under Fiat and Commodity Standards." Journal of Political Economy, December 1997, pp. 1308-21 
Roosa, Robert V. Federal Reserve Operations in the Money and Government Securities Market. Federal Reserve Bank of New York, 1956.

Samuelson, Paul A. "Reflections on Monetary Policy." Review of Economics and Statistics, August 1960, pp. 263-69.

Newsweek, 2 August 1971, p. 70.

and Solow, Robert M. "Problem of Achieving and Maintaining a Stable Price Level: Analytical Aspects of Anti-Inflation Policy." American Economic Review, Papers and Proceedings, May 1960, pp. 177-94.

Sargent, Thomas J. The Conquest of American Inflation. Princeton: Princeton University Press, 1999.

Stone, Courtenay C. and Thornton, Daniel L. "Solving the 1980s’ Velocity Puzzle: A Progress Report.” Federal Reserve Bank of St. Louis Review, August/September 1987, 69(7), pp. 5-23.

Taylor, John B. "Discretion Versus Policy Rules in Practice." Carnegie-Rochester Conference Series on Public Policy, December 1993, pp. 195-214.

"The Robustness and Efficiency of Monetary Policy Rules as Guidelines for Interest Rate Setting by the European Central Bank." Journal of Monetary Economics, June 1999, pp. 655-79.

Weintraub, Sidney. "Monetary Policy, 1957-59: Too Tight, Too Often." Review of Economics and Statistics, August 1960 , pp. 279-82.

Wheelock, David C. "Monetary Policy in the Great Depression and Beyond: The Sources of the Fed's Inflation Bias," in Mark Wheeler, ed. The Economics of the Great Depression. Kalamazoo: The Upjohn Institute, 1998, pp. 127-69.

"National Monetary Policy by Regional Design: The Evolving Role of the Federal Reserve Banks in Federal Reserve System Policy," in Jürgen von Hagen and Christopher J. Waller, eds. Regional Aspects of Monetary Policy in Europe. Boston: Kluwer Academic Publishers, 2000, pp. 241-74.

Woodford, Michael. "Revolution and Evolution in Twentieth-Century Macroeconomics," in P. Gifford, ed. Frontiers of the Mind in the Twenty-First Century. Cambridge, MA: Harvard University Press (forthcoming), $<$ www.princeton.edu/ woodford/macro20C.pdf > .

Yohe, William P. and Karnosky, Denis S. "Interest Rates and Price Level Changes, 1952-69." Federal Reserve Bank of St. Louis Review, December 1969, 51(12), pp. 18-38. 


\section{Appendix}

The first version of the St. Louis monetarist model appeared in Andersen and Carlson (1970), Exhibit 1. It is summarized below. For a comparison of the original and last versions of the model, see Carlson (1986).

Total Spending Equation

1) $\Delta Y_{t}=f_{1}\left(\Delta M_{t} \ldots \Delta M_{t-n}, \Delta E_{t} \ldots \Delta E_{t-n}\right)$

Price Equation

2) $\Delta P_{t}=f_{2}\left(D_{t} \ldots D_{t-n}, \Delta P^{A}\right)$

Demand Pressure Identity

3) $D_{t}=\Delta Y_{t}-\left(X_{t}^{F}-X_{t-1}\right)$

Total Spending Identity

4) $\Delta Y_{t}=\Delta P_{t}+\Delta X_{t}$

Interest Rate Equation

5) $R_{t}=f_{3}\left(\Delta M_{t}, \Delta X_{t} \ldots \Delta X_{t-n}, \Delta P_{t}, \Delta P_{t}^{A}\right)$

Anticipated Price Equation

6) $\Delta P_{t}^{A}=f_{4}\left(\Delta P_{t-1} \ldots \Delta P_{t-n}\right)$

Unemployment Rate Equation

7) $U_{t}=f_{5}\left(G_{t}, G_{t-1}\right)$

GNP Gap Identity

8) $G_{t}=\left(X_{t}^{F}-X_{t}\right) / X_{t}^{F}$
Exogenous Variables:

$\Delta M_{t}=$ change in money stock

$\Delta E_{t}=$ change in high-employment Federal expenditures

$X_{t}^{F}=$ potential output

Endogenous Variables:

$\Delta Y_{t}=$ change in total spending (nominal GNP)

$\Delta P_{t}=$ change in price level (GNP deflator)

$D_{t}=$ demand pressure

$\Delta X_{t}=$ change in output (real GNP)

$R_{t}=$ market interest rate

$\Delta P_{t}^{A}=$ anticipated change in price level

$U_{t}=$ unemployment rate

$G_{t}=$ GNP gap 